\title{
Implementasi Algoritma Username, Resolution, Color, and Hash Dalam Otentikasi Login Sistem
}

\author{
Eza Budi Perkasa \\ STMIK Atma Luhur \\ Pangkalpinang, Indonesia \\ ezabudiperkasa@atmaluhur.ac.id
}

\begin{abstract}
Abstrak - Algoritma Username, Resolution, Color, and Hash (URCH) adalah sebuah algoritma yang digunakan dalam proses otentikasi login sistem. Algoritma ini bekerja dengan empat tahap pemeriksaan data. Dalam algoritma ini, pemeriksaan data tidak hanya dilakukan pada username dan password saja, melainkan juga passimage. Teknik pemeriksaan data tersebut merupakan penggabungan dari teknik kriptografi (fungsi hash) dan steganografi (metode Least Significant Bit) pada citra digital. Penelitian ini akan memaparkan cara mengimplementasikan algoritma URCH ke dalam sebuah aplikasi sederhana. Diharapkan algoritma URCH dapat menjadi standar dalam algoritma otentikasi login sistem.
\end{abstract}

Kata kunci - Fungsi hash, kriptografi, metode Least Significant Bit, otentikasi login, steganografi

\section{Pendahuluan}

Masalah keamanan dan kerahasiaan data merupakan salah satu aspek penting dari suatu sistem informasi. Ketika berbicara mengenai masalah keamanan yang berkaitan dengan penggunaan komputer, umumnya hal utama yang dibahas adalah mengenai kriptografi. Kriptografi merupakan suatu ilmu yang mepelajari cara menjaga data atau pesan tetap aman saat dikirimkan dari pengirim ke penerima tanpa mengalami gangguan dari pihak lain [1]. Data atau pesan yang dikirim tidak boleh jatuh ke tangan orang yang tidak berhak ataupun tidak berkepentingan [2]. Kriptografi itu sendiri bertujuan untuk memberikan layanan keamanan, termasuk keamanan untuk menjaga kerahasiaan dari password. Password yang telah dimiliki tidak boleh jatuh ke tangan orang yang tidak berhak ataupun tidak berkepentingan. Password biasanya digunakan untuk layanan otentikasi, baik otentikasi kebenaran pihak-pihak yang berkomunikasi maupun otentikasi kebenaran sumber pesan.

Untuk menjaga keamanan dari password, dapat dilakukan dengan cara mengubah password (plaintext) menjadi ciphertext melalui proses enkripsi. Adapun proses pengembalian ciphertext menjadi plaintext kembali disebut sebagai proses dekripsi [3]. Dikarenakan cara ini memiliki kekurangan -yaitu panjang ciphertext selalu sama dengan plaintext sehingga plaintext dapat ditebak dengan menghitung frekuensi kemunculan karakter, digunakan teknik lain yang disebut dengan fungsi hash. Fungsi ini merupakan fungsi satu arah, sehingga ketika password sudah di-hash, maka hash password tersebut tak dapat dikembalikan menjadi password semula. Adapun panjang hash suatu password adalah sama untuk password dengan panjang berapapun juga [4]. Akan tetapi, ternyata fungsi hash pun memiliki kelemahan. Jika diberikan dua buah password yang berbeda, maka terdapat kemungkinan bahwa kedua password tersebut memiliki hash yang sama. Ini mengakibatkan seorang user yang lupa dengan password saat masuk ke dalam sistem dapat menggunakan password lain yang memiliki hash sama tanpa mengubah passwordnya terlebih dahulu.

Pada umumnya, otentikasi login sistem dilakukan dalam dua sampai tiga tahap. Otentikasi login yang dilakukan dalam dua tahap meliputi pemeriksaan username dan hash password yang di-input. Sementara otentikasi login yang dilakukan dalam tiga tahap memiliki teknik pemeriksaan lainnya, misalnya dengan menambahkan captcha. Captcha bertujuan untuk meyakinkan bahwa user yang memasukkan data ke dalam form login adalah benar-benar manusia dan bukan program yang digunakan untuk login otomatis (misalnya, bot). Captcha merupakan berkas multimedia yang di dalamnya terekam kode acak yang harus disalin user ke dalam textbox yang disediakan. Terkadang captcha justru membingungkan user, terutama captcha yang berupa gambar sederetan karakter yang diletakkan secara acak juga dan capitalization karakter yang hampir sama satu dengan yang lainnya.

Dalam penelitian ini, penulis bermaksud untuk membahas sebuah teknik otentikasi login sistem yang bernama algoritma URCH (Username, Resolution, Color, and Hash). Algoritma ini merupakan penggabungan dari teknik kriptografi (fungsi hash) dan steganografi (metode Least Significant Bit) pada citra digital. Keunggulan dari algoritma ini adalah data-data user akan dimasukkan ke dalam sebuah gambar. Gambar tersebut nantinya akan digunakan untuk memeriksa kebenaran data dalam form login yang telah di-input oleh sistem. Gambar penampung data user ini tentu tidak jauh berbeda dengan gambar aslinya, sehingga kerahasiaan data dapat terjamin.

\section{Metodologi Penelitian}

\section{A. Algoritma URCH}

Algoritma URCH (Username, Resolution, Color, and Hash) adalah salah satu algoritma dalam proses otentikasi login sistem. Sesuai dengan namanya, algoritma URCH memeriksa data yang dimasukkan dalam form login melalui empat tahap. Keempat tahap tersebut adalah sebagai berikut. 
1) Pemeriksaan username (tahap U);

2) Pemeriksaan resolusi/ukuran passimage (tahap R);

3) Pemeriksaan matriks warna passimage (tahap C); dan

4) Pemeriksaan hash dari password (tahap $\mathrm{H}$ ).

Algoritma ini merupakan sebuah inovasi baru dalam otentikasi login sistem. Selama ini, biasanya seorang user akan diberikan ID dan password. Untuk menampilkan portrait dirinya, user tersebut biasanya mengunggah foto diri ataupun gambar lainnya yang menjadi ciri khas dari sang user (seperti dalam situs jejaring sosial dan forum). Permasalahannya, gambar tersebut hanya menjadi hiasan semata sehingga user dapat menggantinya sesuka hati. Dalam algoritma URCH, gambar tersebut tidak hanya berfungsi sebagai penunjuk identitas dari seorang user saja: Jika user mengganti gambarnya, maka ia pun akan mengubah identitasnya. Hal ini berbeda dengan pemikiran sebelumnya bahwa jika user mengganti gambarnya, maka identitasnya belum tentu akan berubah. Adapun algoritma otentikasi login sistem konvensional selanjutnya disebut sebagai algoritma UH (Username and $\boldsymbol{H}$ ash). Algoritma tersebut dinamai demikian karena pemeriksaan datanya hanya melalui dua tahap saja (pemeriksaan username dan hash dari password) walaupun terkadang beberapa sistem menambahkan metode captcha untuk mempertegas bahwa user yang dimaksud bukanlah mesin login otomatis.

Dengan algoritma URCH, privasi dari user akan semakin terjaga. Hal ini disebabkan data user untuk pengujian validitas terekam dari gambar yang diunggah oleh user. Gambar tersebut tidak akan terlihat berbeda oleh kasat mata karena penyisipan datanya menggunakan metode steganografi LSB. Pemeriksaan gambar yang diunggah sepenuhnya dilakukan oleh komputer tanpa campur tangan manusia. Pemeriksaan gambar dilakukan dengan cara membandingkan gambar asli dan gambar yang diunggah oleh user. Jika gambar unggahan terlihat sama dengan gambar asli, maka pemeriksaan dilanjutkan dengan pengecekan bit-bit warna gambar unggahan. Jika terdapat sedikit saja perbedaan pada bit-bit tersebut dibandingkan dengan bit-bit pada gambar asli, maka dapat dikatakan bahwa data user yang di-input valid.

\section{B. Perekaman Pesan ke Passimage}

Secara praktis, passimage dapat dianalogikan dengan password. Perbedaan keduanya hanya terletak pada hal yang menjadi persyaratan: Passimage mensyaratkan gambar dan password mensyaratkan kata. Dalam penelitian ini, passimage yang dimaksud bukan sekedar gambar biasa, namun berupa gambar yang memiliki pesan terekam di dalamnya. Pengisian data ini dilakukan secara column major order (CMO) pada matriks gambar dan menerapkan metode LSB untuk tata cara pengisiannya.

Col $1 \mathrm{Col} 2 \mathrm{Col} 3 \mathrm{Col} 4 \mathrm{Col} 5$



Gambar 1 Column Major Order

Misalkan terdapat matriks passimage berikut.

$\begin{array}{cccccc}222 & 43 & 7 & 131 & 97 & 159 \\ 248 & 251 & 21 & 233 & 123 & 201 \\ 52 & 84 & 64 & 253 & 203 & 59 \\ 123 & 0 & 104 & 208 & 186 & 172 \\ 148 & 191 & 155 & 235 & 174 & 235 \\ 61 & 234 & 43 & 239 & 94 & 175 \\ 240 & 7 & 135 & 148 & 25 & 217 \\ 85 & 221 & 188 & 34 & 63 & 185 \\ 121 & 238 & 220 & 160 & 184 & 21\end{array}$

Jika pesan yang akan dimasukkan ke dalam passimage tersebut adalah "Hello", maka bit pesan tersebut adalah 0100100001100101011011000110110001101111. Deretan bit tersebut merupakan penggabungan kode ASCII setiap karakter pada pesan dalam bentuk biner. Untuk memasukkan pesan tersebut ke dalam passimage, pertama-tama ubah setiap elemen matriks passimage menjadi bilangan biner 8 bit. Bilangan biner 8 bit ini dipilih karena matriks passimage sebenarnya adalah matriks dari warna yang digunakan pada setiap piksel yang nilainya berkisar dari 0 hingga $255\left(2^{8}-1\right)$. 


$\begin{array}{llllll}11011110 & 00101011 & 00000111 & 10000011 & 01100001 & 10011111 \\ 11111000 & 11111011 & 00010101 & 11101001 & 01111011 & 11001001 \\ 00110100 & 01010100 & 01000000 & 11111101 & 11001011 & 00111011 \\ 01111011 & 00000000 & 01101000 & 11010000 & 10111010 & 10101100 \\ 10010100 & 10111111 & 10011011 & 11101011 & 10101110 & 11101011 \\ 00111101 & 11101010 & 00101011 & 11101111 & 01011110 & 10101111 \\ 11110000 & 00000111 & 10000111 & 10010100 & 00011001 & 11011001 \\ 01010101 & 11011101 & 10111100 & 00100010 & 00111111 & 10111001 \\ 01111001 & 11101110 & 11011100 & 10100000 & 10111000 & 00010101\end{array}$

Sebelum memasukkan bit-bit pesan, periksalah terlebih dahulu jumlah bit pesan dan jumlah elemen dari matriks passimage. Jika jumlah bit pesan kurang dari atau sama dengan jumlah elemen matriks passimage, maka pesan tersebut dapat dimasukkan ke dalam passimage. Pada contoh, jumlah bit pesan adalah 40 dan jumlah elemen matriks passimage adalah 54. Dengan demikian, pesan tersebut dapat dimasukkan ke dalam passimage. Pesan dimasukkan dengan cara mengganti bit terkanan setiap elemen matriks passimage dengan bit dari pesan dari atas ke bawah, kiri ke kanan.

$\begin{array}{llllll}11011110 & 00101011 & 00000111 & 10000010 & 01100001 & 10011111 \\ 11111001 & 11111011 & 00010100 & 11101001 & 01111011 & 11001001 \\ 00110100 & 01010100 & 01000001 & 11111101 & 11001011 & 00111011 \\ 01111010 & 00000000 & 01101001 & 11010000 & 10111011 & 10101100 \\ 10010101 & 10111111 & 10011010 & 11101010 & 10101110 & 11101011 \\ 00111100 & 11101010 & 00101010 & 11101110 & 01011110 & 10101111 \\ 11110000 & 00000111 & 10000110 & 10010101 & 00011001 & 11011001 \\ 01010100 & 11011100 & 10111101 & 00100011 & 00111111 & 10111001 \\ 01111000 & 11101111 & 11011101 & 10100000 & 10111000 & 00010101\end{array}$

Agar matriks tersebut dapat diubah kembali menjadi warna, konversikan matriks tersebut ke bentuk desimal.

$\begin{array}{cccccc}\mathbf{2 2 2} & \mathbf{4 3} & \mathbf{7} & \mathbf{1 3 0} & \mathbf{9 7} & 159 \\ \mathbf{2 4 9} & \mathbf{2 5 1} & \mathbf{2 0} & \mathbf{2 3 3} & \mathbf{1 2 3} & 201 \\ \mathbf{5 2} & \mathbf{8 4} & \mathbf{6 5} & \mathbf{2 5 3} & \mathbf{2 0 3} & 59 \\ \mathbf{1 2 2} & \mathbf{0} & \mathbf{1 0 5} & \mathbf{2 0 8} & \mathbf{1 8 7} & 172 \\ \mathbf{1 4 9} & \mathbf{1 9 1} & \mathbf{1 5 4} & \mathbf{2 3 4} & 174 & 235 \\ \mathbf{6 0} & \mathbf{2 3 4} & \mathbf{4 2} & \mathbf{2 3 8} & 94 & 175 \\ \mathbf{2 4 0} & \mathbf{7} & \mathbf{1 3 4} & \mathbf{1 4 9} & 25 & 217 \\ \mathbf{8 4} & \mathbf{2 2 0} & \mathbf{1 8 9} & \mathbf{3 5} & 63 & 185 \\ \mathbf{1 2 0} & \mathbf{2 3 9} & \mathbf{2 2 1} & \mathbf{1 6 0} & 184 & 21\end{array}$

Pada keadaan sebenarnya, matriks warna pada gambar berukuran lebih besar. Selain itu, setiap gambar pun memiliki komposisi warnanya sendiri-sendiri. Sebagai contoh, gambar grayscale hanya memiliki satu komposisi warna, gambar RGB memilki tiga komposisi warna, dan gambar CMYK memiliki empat komposisi warna. Akibat dari komposisi warna ini, matriks yang dihasilkan tidak berupa matriks dua dimensi seperti dikenal selama ini, melainkan berupa matriks tiga dimensi. Dimensi ketiga dari matriks warna ini merupakan komposisi. Komposisi warna dapat diibaratkan tinggi atau kedalaman pada sebuah balok. Dalam penelitian ini, gambar yang digunakan dibatasi pada gambar grayscale dan RGB saja. Namun, tidak menutup kemungkinan gambar dengan komposisi lainnya dapat digunakan sebagai passimage juga.

Dalam gambar grayscale, pengisian data dengan CMO dilakukan seperti biasa, yaitu dari atas ke bawah, kiri ke kanan. Sedangkan pada gambar RGB, pengisian data tersebut juga mempertimbangkan komposisi warnanya. Komposisi warna pada gambar RGB terdiri dari Red (merah), Green (hijau), dan Blue (biru). Jika telah mencapai baris terakhir dan kolom terakhir pada komposisi R, maka data sisa diisi mulai dari baris pertama dan kolom pertama komposisi G. Jika telah mencapai batas akhir komposisi $\mathrm{G}$ dan masih terdapat sisa data yang belum dimasukkan, maka sisa data tersebut dimasukkan ke dalam komposisi B. Adapun untuk menyatakan resolusi dari gambar, tidak perlu menyebutkan jumlah komposisi warna, melainkan cukup dengan menyebutkan jumlah baris dan jumlah kolom saja. Komposisi warna hanya diperlukan saat tahap C dalam otentikasi login dengan 
algoritma URCH untuk pengecekan apakah passimage yang dimasukkan sama dengan gambar dalam sistem karena perbedaan sedikit saja dalam warna pada piksel passimage akan mempengaruhi keabsahan data yang dimasukkan.

Perekaman data ke dalam passimage dengan metode LSB tidak akan menimbulkan perubahan secara kasat mata. Akan tetapi, komputer mampu membedakan warna piksel karena setiap warna - walaupun hanya berubah sedikit- memiliki kodenya masingmasing. Kode ini biasanya dinyatakan dalam bentuk heksadesimal dengan format \#RRGGBB. Setiap digit heksadesimal mewakili empat bit bilangan biner sehingga setiap komposisi warna memilki dua digit heksadesimal. Sebagai contoh, warna merah murni memilki kode \#ff0000. Kode tersebut dapat dinyatakan dalam biner menjadi 111111110000000000000000 . Untuk membuktikan bahwa metode LSB tak menimbulkan perubahan secara kasat mata, perhatikan Tabel 1 yang menampilkan perubahan bit warna dan warna yang dihasilkan setelah perubahan.

Tabel 1 Contoh Penerapan Metode LSB

\begin{tabular}{|c|c|c|c|c|}
\hline \multicolumn{2}{|c|}{ Nilai Komposisi (Biner) } & \multirow{2}{*}{ Sampel } & \multirow{2}{*}{$\begin{array}{c}\text { Kode } \\
\text { Warna }\end{array}$} \\
\hline R & G & B & & \#ff0000 \\
\hline 1111111 & 00000000 & 00000000 & & \#fe0000 \\
\hline 11111110 & 00000000 & 00000000 & & \#ff0100 \\
\hline 1111111 & 00000001 & 00000000 & & \#ff0001 \\
\hline 1111111 & 00000000 & 00000001 & & \#fe0100 \\
\hline 11111110 & 00000001 & 00000000 & & \#fe0001 \\
\hline 11111111 & 00000000 & 00000001 & & \#ff0101 \\
\hline 11111110 & 00000001 & 00000001 & & \#fe0101 \\
\hline
\end{tabular}

Dari tabel tersebut, terlihat bahwa pengubahan sedikit pada bit nilai komposisi tak mempengaruhi warna secara kasat mata. Bahkan di perangkat pengolah kata penulis, sampel warna yang diambil tersebut semuanya dikenali sebagai "Red". Pengubahan tersebut hanya berdampak pada kode warna yang dihasilkan.

\section{Stegohash}

Pada penelitian ini, penulis menggunakan dua fungsi hash sekaligus: MD5 dan SHA1. Penggunaan kedua fungsi hash tersebut bertujuan untuk mengurangi resiko terjadinya collision karena sebagaimana diketahui, penggunaan satu fungsi hash saja dapat menghasilkan nilai hash yang dapat dimilki sedikitnya dua buah password yang berbeda. Dengan menggunakan dua fungsi hash, kemungkinan nilai sama tersebut dapat diperkecil. Dua fungsi hash yang digunakan tersebut selanjutnya disebut sebagai stegohash.

Stegohash adalah penggabungan nilai dari fungsi-fungsi hash yang berbeda dengan model steganografi. Dalam penelitian ini, stegohash ditentukan dengan memasukkan setiap digit heksadesimal pada hash SHA1 berselang-seling dengan digit heksadesimal pada hash MD5. Karena jumlah digit heksadesimal MD5 lebih sedikit daripada SHA1 (MD5 mempunyai 32 digit, sedangkan SHA1 mempunyai 40 digit), maka akan terdapat sisa digit. Sisa digit ini diisi sepenuhnya dengan digit-digit sisa dari SHA1. Sebagai contoh, seorang user memilki akun dengan password "user123" (tanpa tanda petik). Nilai hash MD5 password ini adalah

\section{6ad14ba9986e3615423dfca256d04e3f}

dan nilai hash SHA1-nya adalah

$$
\text { 95c946bf622ef93b0a211cd0fd028dfdfcf7e39e }
$$

Jadi, nilai stegohash dari password sang user tersebut adalah

\section{5 acd 91446 bbaf9692826eef39631b504a2231d 1 fccda02f5d60d2084def3dffcf7e $39 \mathrm{e}$.}

Stegohash ini selanjutnya digabungkan dengan username. Jika username dari user tersebut adalah "maniac_user" (tanpa tanda petik), maka penggabungan stegohash dan username-nya menjadi maniac_user965acd $91446 \mathbf{b b a f 9 6 9 2 8 2 6 e e f 3 9 6 3 1}$ b504a2231d d fccda02f5d60d2084def3dffcf7e39e.

Hasil dari penggabungan inilah yang selanjutnya dimasukkan ke dalam passimage. Tentu saja, string tersebut tidak langsung dimasukkan, melainkan harus dikonversi ke dalam deretan bit terlebih dahulu. Pengonversian ini dilakukan dengan ketentuan setiap digit stegohash diperlakukan sebagai karakter biasa, bukan angka. Dengan demikian, pengonversian dari penggabungan username dan stegohash pada contoh ke deretan bit menjadi 
Deretan bit inilah yang dimasukkan ke dalam passimage dengan cara yang sama dengan perekaman pesan ke dalam passimage yang telah diuraikan sebelumnya.

Untuk memeriksa keabsahan data yang dimasukkan ke dalam form login, pertama-tama komputer akan mengekstrak hiddentext dari passimage (dengan asumsi passimage yang dimasukkan sudah benar). Hiddentext ini tidak lain merupakan penggabungan username dan stegohash yang terekam dan sudah dikonversi ke dalam bentuk karakter. Karena jumlah karakter dalam stegohash adalah tetap -yaitu 32 karaker dari MD5 + 40 karakter dari SHA1 = 72 karakter, maka dapat dipastikan bahwa 72 karakter terakhir hiddentext adalah hash password yang benar dan karakter-karakter awal dari hiddentext adalah username yang benar. Jika username dan hash password yang dimasukkan sama dengan data pada hiddentext, maka user tersebut dapat memasuki halaman/ form utama dari aplikasi.

D. Algoritma

Secara ringkas, algoritma URCH dalam proses otentikasi login sistem dapat dijabarkan sebagai berikut.

1) User memasukkan username, password, dan passimage.

2) Komputer akan melakukan pengekstrakan hiddentext dari passimage.

3) Jika username yang dimasukkan sama dengan username yang ditemukan pada hiddentext, maka pemeriksaan dilanjutkan. Jika tidak, maka kembali ke langkah pertama.

4) Jika resolusi gambar yang tersimpan pada sistem sama dengan resolusi passimage (tanpa memperhatikan komposisi warna keduanya), maka pemeriksaan dilanjutkan. Jika tidak, maka kembali ke langkah pertama.

5) Jika matriks warna pada gambar yang tersimpan pada sistem sama dengan matriks warna pada passimage, maka pemeriksaan dilanjutkan. Jika tidak, maka kembali ke langkah pertama.

6) Jika nilai stegohash password yang dimasukkan sama dengan stegohash password yang ditemukan pada hiddentext, maka form utama akan ditampilkan. Jika tidak, maka kembali ke langkah pertama.

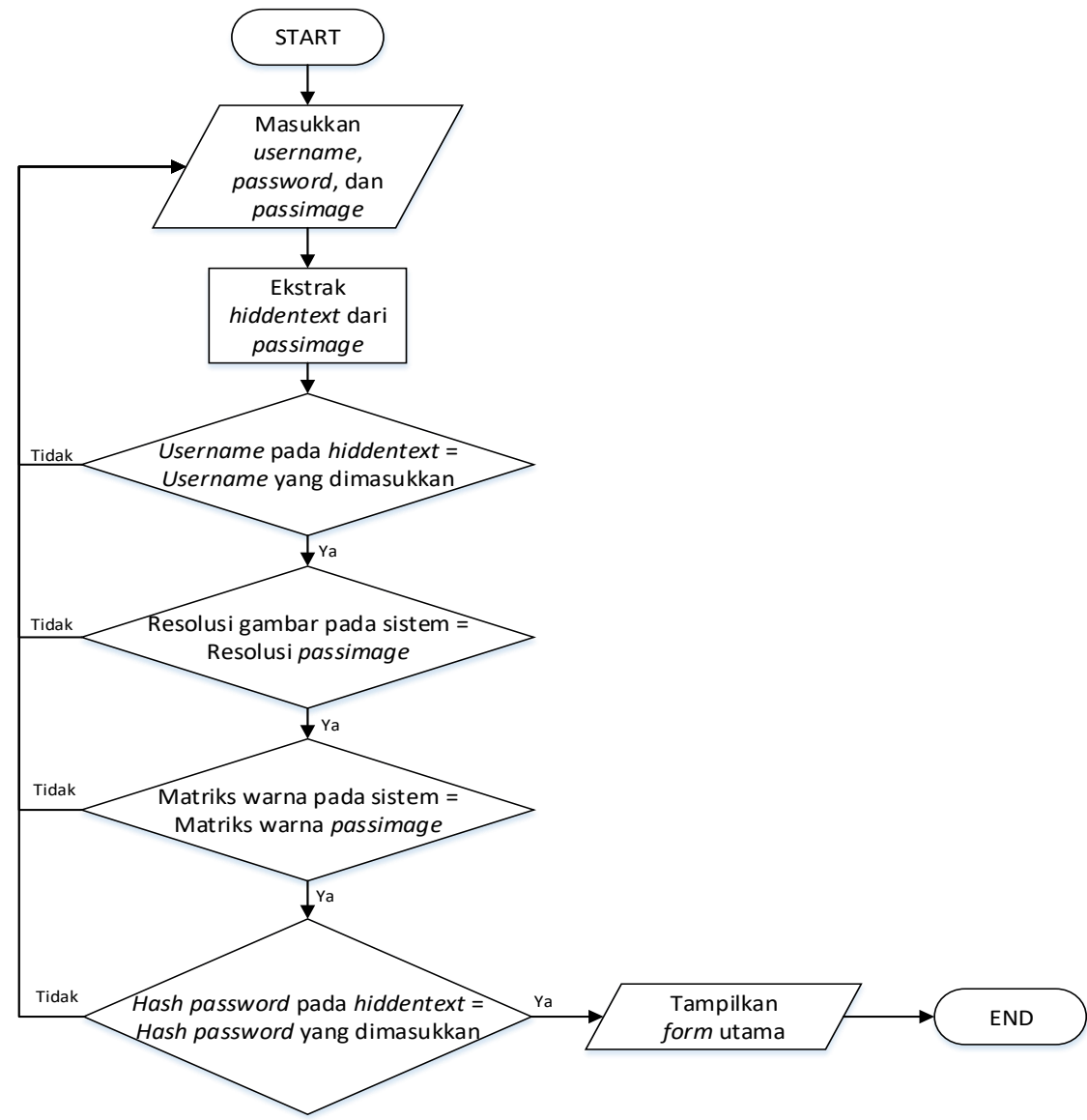

Gambar 2 Algoritma URCH

\section{HASIL DAN PEMBAHASAN}

\section{A. Implementasi}

Sistem yang dibuat untuk melakukan uji coba adalah sebuah sistem informasi akademik dari sebuah universitas fiktif. Form yang digunakan untuk login ke sistem tersebut dapat dilihat pada Gambar 3. 


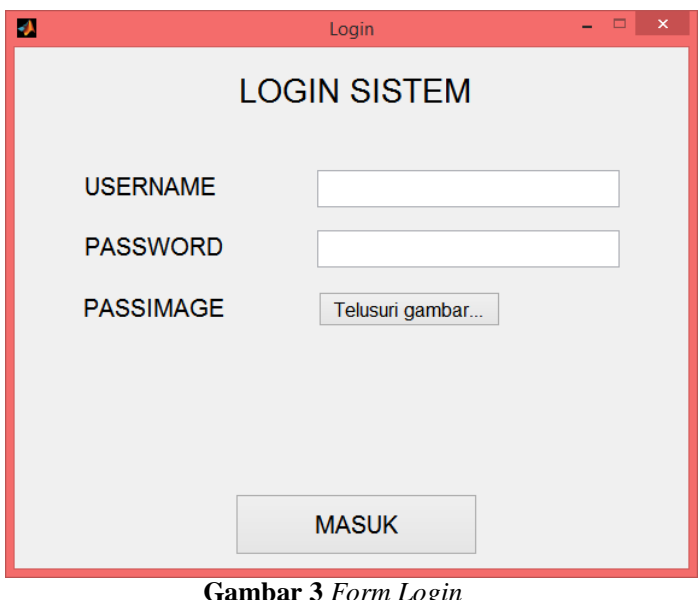

Untuk masuk ke form utama seperti terlihat pada Gambar 4, user diharuskan untuk memasukkan username dan password yang benar serta meng-upload passimage yang benar dengan mengklik tombol "Telusuri gambar...".

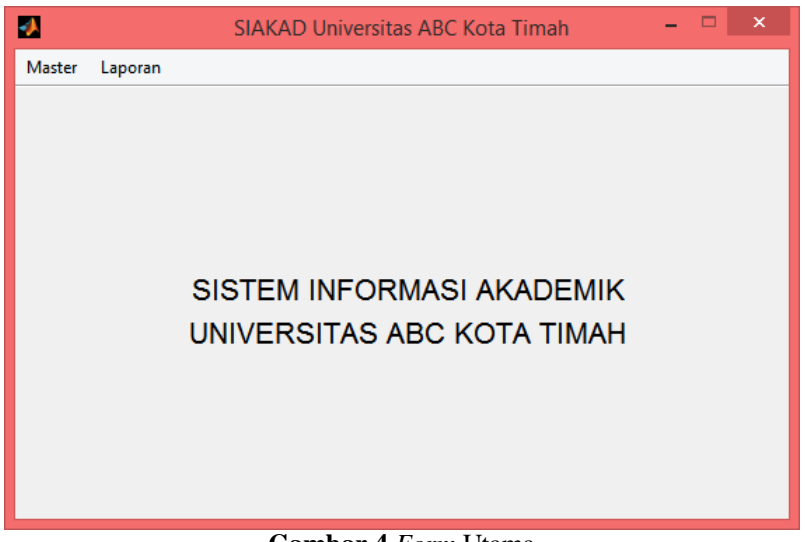

Gambar 4 Form Utama

\section{B. Pengujian}

Pengujian kali ini dilakukan dengan cara mencoba memasukkan data ke dalam form login. Pengujian akan dilakukan beberapa kali hingga terdapat data yang benar sehingga form utama dapat ditampilkan. Tabel 2 dan Tabel 3 menunjukkan data-data yang akan diuji.

Tabel 2 Gambar yang Digunakan Dalam Pengujian

\begin{tabular}{|l|l|l|l|}
\hline Gambar & Nama Gambar & Resolusi & Komposisi Warna \\
\hline & & & \\
\hline
\end{tabular}




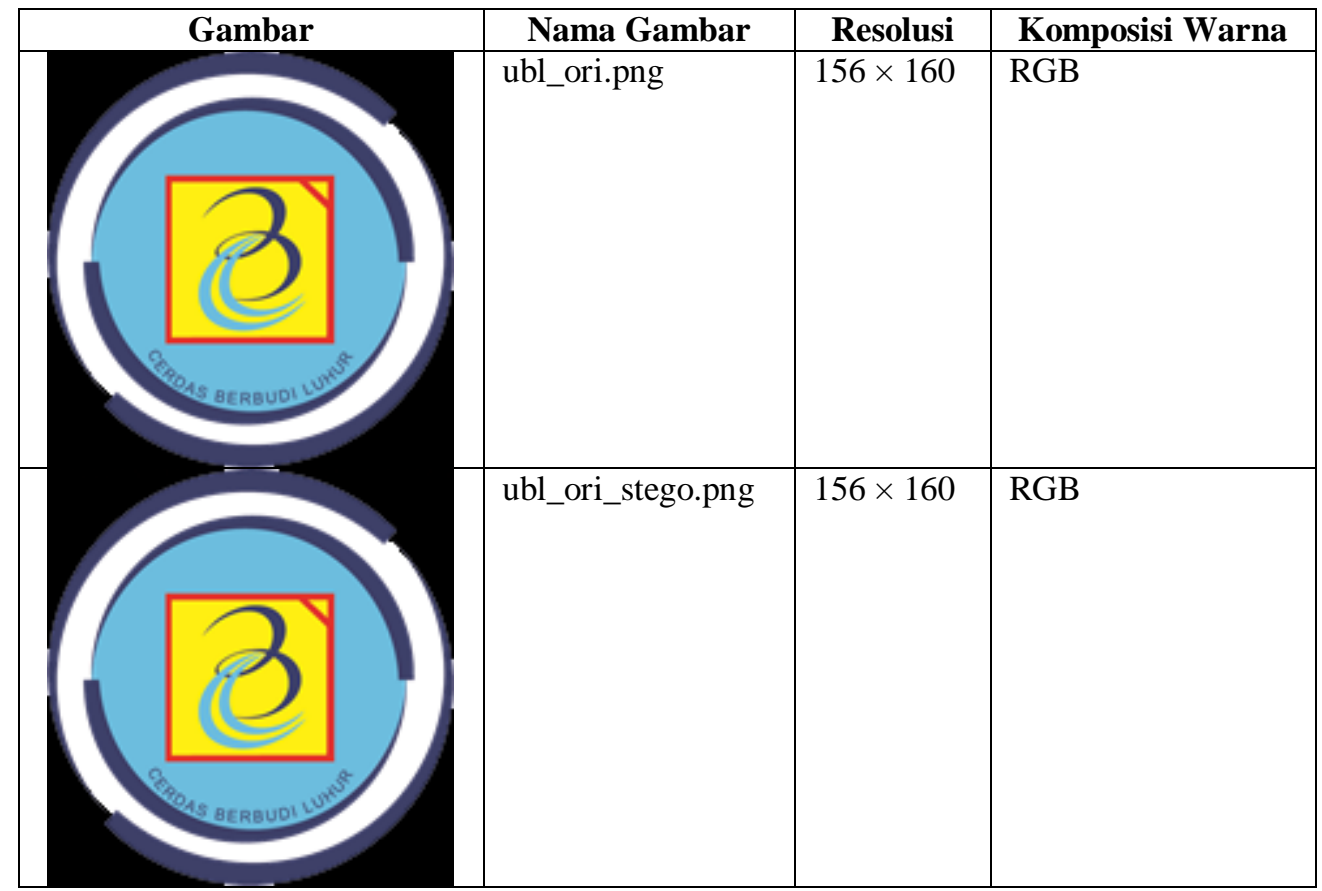

Keempat gambar tersebut sepintas terlihat sama dengan pasangannya masing-masing (gambar dengan tanpa akhiran nama dan nama dengan akhiran_stego). Akan tetapi, dari dua pasang gambar itu, hanya terdapat satu gambar yang merupakan passimage yang valid.

Tabel 3 Username dan Password yang Digunakan Dalam Pengujian

\begin{tabular}{|l|l|}
\hline \multicolumn{1}{|c|}{ Username } & \multicolumn{1}{c|}{ Password } \\
\hline user & 12345 \\
\hline admin & admin \\
\hline
\end{tabular}

Hasil pengujian terhadap data-data tersebut dapat dilihat pada Tabel 4.

Tabel 4 Hasil Pengujian

\begin{tabular}{|c|l|l|l|c|}
\hline Percobaan & Username & Password & \multicolumn{1}{|c|}{ Passimage } & Form Utama Tampil ? \\
\hline I & user & 12345 & ubl_bw.png & Tidak \\
\hline II & admin & admin & ubl_bw.png & Tidak \\
\hline III & user & 12345 & ubl_bw_stego.png & Tidak \\
\hline IV & admin & admin & ubl_bw_stego.png & Tidak \\
\hline V & user & 12345 & ubl_ori.png & Tidak \\
\hline VI & admin & admin & ubl_ori.png & Tidak \\
\hline VII & user & 12345 & ubl_ori_stego.png & Tidak \\
\hline VIII & admin & admin & ubl_ori_stego.png & Ya \\
\hline
\end{tabular}

Dari tabel tersebut, dapat dilihat pada percobaan VIII, form utama dapat ditampilkan karena data yang dimasukkan sudah benar. Dengan demikian, data yang valid pada pengujian kali ini adalah sebagai berikut.

\section{Username: admin}

Password: admin

Passimage: ubl_ori_stego.png

Resolusi passimage: $156 \times 160$

Komposisi warna passimage: RGB

Hiddentext dalam passimage:

admind2013233e22f22a 9e73a 4587aae5ba57646308f9c42a104e04aae8c0315f8c530c4da 997

\section{PENUTUP}

A. Kesimpulan

Dari hasil penelitian penulis mengenai algoritma URCH dalam otentikasi login sistem, maka dapat diambil kesimpulan berikut. 
1) Algoritma URCH dapat diimplementasikan dengan cara memasukkan field input tambahan berupa passimage pada form login, selain username dan password yang sudah dikenal selama ini.

2) Dalam proses otentikasi, passimage tersebut turut diperiksa untuk mendapatkan data masukan yang benar.

3) Passimage memiliki sedikit perbedaan yang tak tampak kasat mata dengan gambar aslinya.

4) Passimage dapat digunakan sebagai penunjuk identitas user ketika berinteraksi dengan user lain karena data yang terdapat di dalamnya tersamarkan sehingga aman digunakan tanpa khawatir mengenai kerahasiaan data tersebut.

B. Saran

Penelitian ini masih jauh dari sempurna. Oleh karena itu, penulis memberikan saran-saran berikut untuk penelitian selanjutnya.

1) Menggunakan fungsi hash lain dalam penyimpanan password dan membandingkan hasilnya.

2) Menggunakan metode steganografi lainnya untuk pembuatan passimage.

\section{PENGAKUAN}

Makalah ini dibuat untuk memenuhi salah satu komponen dalam Tri Dharma Perguruan Tinggi dan disponsori oleh Lembaga Penelitian dan Pengabdian Masyarakat STMIK Atma Luhur.

\section{DAFTAR PUSTAKA}

[1] E. Handayani, W. L. Pratitis, A. Nur, S. A. Mashuri, dan B. Nugroho, "Perancangan Aplikasi Kriptografi Berbasis Web Dengan Algoritma Double Caesar Cipher Menggunakan Tabel ASCII," dalam Seminar Nasional Teknologi Informasi dan Multimedia 2017, 2017 , hal. 241-246.

[2] C. A. Sari, E. H. Rachmawanto, D. W. Utomo, dan R. R. Sani, "Penyembunyian Data Untuk Seluruh Ekstensi File Menggunakan Kriptografi Vernam Cipher dan Bit Shiffting," Journal of Applied Intelligent System, vol. 1, hal. 179-190, Okt. 2016.

[3] R. K. Hondro. "Aplikasi Enkripsi dan Dekripsi SMS Dengan Algoritma Zig Zag Cipher Pada Mobile Phone Berbasis Android," Pelita Informatika Budi Darma, vol. X, Jul. 2015.

[4] K. Aryasa dan Y. T. Paulus, "Implementasi Secure Hash Algorithm-1 Untuk Pengamanan Data Dalam Library Pada Pemrograman Java," Citec Journal, vol. 1, hal. 57-66, Nov. 2013. 